\title{
PERAN PENDIDIKAN PANCASILA DAN KEWARGANEGARAAN DALAM BIMBINGAN KONSELING
}

\author{
Oleh: \\ Nova Eko Hidayanto \\ Prodi PPKn, Institut Keguruan dan Ilmu Pendidikan (IKIP) PGRI Jember \\ e-mail: abdianatocamilan@gmail.com
}

\begin{abstract}
We know that how important BK (Counseling Guidance) in campus and secondary school until senior high school. Remember that now is globalization or modern era which is how heavy information from foreign country that do not bring fine cases which accordance with our country personality that is Pancasila. Lately, many decadence moral like student or society fighting, drug and alcohol drinking, et cetera. Even especially many victim of alcohol drinking are student of very young people and this is become central of attention from our state, Indonesia, not only now but forever. Because of that, alcohol drinking which is easy gotten and identical with appearance of discotiques which is come from foreign country. Of course drug and alcohol drinking can cause death accordance with medical science and destroy of education world. In one side, BK role is helping and pushing service to all student for to speed their study with giving advices so that can filter negative acts which can not accordance with Pancasila and religion. In this, BK role must join with religion and PPKN teacher for helping better student in Indonesia.
\end{abstract}

Kata Kunci : Role, Pancasila and Civic, Counseling Guide

\section{PENDAHULUAN}

\section{A. Latar Belakang}

Kita semua sebagai warga negara Indonesia telah mengetahui sebelumnya bahwa Pancasila adalah merupakan dasar negara kita yaitu Indonesia. Hal ini berarti Pancasila mempunyai kedudukan yang paling mendasar dalam semua sendi kehidupan bangsa Indonesia itu sendiri. Semua sendi kehidupan itu baik pemerintahan maupun non pemerintahan, baik dari pejabat tertinggi sampai pejabat terendah dan semua rakyat Indonesia. Hal tersebut berarti segala peraturan dan tingkah laku semua rakyat Indonesia (baik seluruh pejabat Pemerintah maupun bukan pejabat Pemerintah) harus berdasarkan Pancasila. Jadi jika ada yang tidak sesuai dengan Pancasila maka harus ditindak sesuai dengan kadar kesalahannya. Hal ini sesuai pendapat Soeroso (2007: 120) yang menyatakan bahwa "Pancasila adalah sumber tertib hukum yang pertama". 
Yang menindak bukan hanya Pemerintah tetapi juga oleh semua rakyat Indonesia. Contoh tindakan dari rakyat yaitu hukum yang tidak tertulis atau hukum adat yang masih berlaku di seluruh wilayah Indonesia. Hal ini tentunya walaupun hukum tidak tertulis atau hukum adat tetapi sesuai dengan nilai- nilai Pancasila itu sendiri, karena nilai- nilai Pancasila diambil dari budaya luhur kepribadian bangsa Indonesia itu sendiri. Hukum tidak tertulis atau hukum adat itu disebut juga dengan hukum moral atau dikatakan moral saja. Menurut pendapat Soeroso (2007: 45) :

Bahwa hukum itu adalah suatu kaidah biasa seperti kesusilaan, moral dan agama. Hanya perbedaannya dengan kaidah- kaidah lainnya ialah bahwa norma hukum menjadi norma yang terutama dipertahankan oleh suatu pemerintah negara. Tapi bagi manusia kaidah- kaidah hukum itu bukanlah satusatunya peraturan, ia mengenal dan menaati juga kaidah- kaidah agama, kesusilaan, adat dan kebiasaan yang sama- sama penting baginya.

\section{B. Rumusan Masalah}

Terkait dengan hal- hal diatas yaitu maka dapat dirumuskan beberapa masalah yaitu :

1. Bagaimana peran PPKn dalam BK (Bimbingan Konseling) ?

2. Apa saja peran PPKn dalam BK (Bimbingan Konseling) ?

\section{PEMBAHASAN}

Pentingnya PPKN (Pendidikan Pancasila dan Kewarganegaraan)

Telah disebutkan diatas bahwa Pancasila merupakan dasar negara kita yaitu Indonesia, maka oleh karena itu segala tingkah laku rakyatnya mau tidak mau harus berdasarkan pada Pancasila. Yang dimaksud rakyat adalah baik sebagai warga negara Indonesia asli maupun siapa saja yang telah memasuki wilayah Indonesia. Oleh karena itu bagi warga luar negeri yang ingin memasuki wilayah RI dengan segala tujuan maka mau tidak mau harus mengenal apa Pancasila itu dan sejarah kemerdekaan RI terlebih dahulu.

Beberapa manfaatnya bagi
orang asing atau luar negeri yaitu
menyelamatkan diri agar tidak
melanggar ketentuan- ketentuan baik
mengenai hukum maupun non-
hukum di wilayah Indonesia. Yang
berkaitan dengan non- hukum
misalnya masalah pergaulan dan
tingkah laku dengan rakyat


Indonesia, sehingga orang tersebut menyesuaikan dengan Pancasila.

Pengenalan tentang Pancasila dan sejarah kemerdekaan RI bukan saja menjadi kewajiban bagi orang asing saja tetapi juga khususnya bagi warga negara Indonesia itu sendiri terutama pada generasi mudanya dari tingkat PAUD sampai Pergurruan Tinggi dan juga pendidikan formal dan non formal. Pemerintah juga berkewajiban menyebarkan pengenalan Pancasila dan sejarah kemerdekaan RI melalui media massa.

Mengenai tujuan pendidikan Pancasila menurut Heru dan kawankawan (2002:3) :

Surat Keputusan Ditjen Dikti Nomor 265 Tahun 2000 dijelaskan bahwa untuk mencapai tujuan pendidikan nasional, wajib diberikan mata kuliah Pendidikan Pancasila kepada peserta didik. Pendidikan Pancasila dirancang dengan maksud untuk memberikan pengertian kepada mahasiswa tentang Pancasila sebagai filsafat atau Tata Nilai Bangsa, sebagai Dasar Negara dan Ideologi dengan segala implikasinya. Pendidikan Pancasila bertujuan untuk menghasilkan peserta didik yang beriman dan bertakwa kepada Tuhan Yang Maha Esa, berperikemanusiaan yang adil dan beradab, mendukung kerakyatan yang mengutamakan kepentingan bersama diatas kepentingan individu atau golongan, mendukung upaya mewujudkan suatu keadilan sosial dalam masyarakat.

Begitu juga kepada anak berkebutuhan khusus (ABK), sesuai dengan pendapat Pujihastuti (2016 : 413) :

Paradigma baru untuk pendidikan bagi ABK adalah menempatkan mereka sama dengan anak normal (reguler) lainnya. Oleh karena itu, sekarang dikenal dengan istilah sekolah inklusi. Menurut Choiri dan Yusuf (2009 : 62) bentuk layanan pendidikan terpadu atau integrasi atau inklusi adalah sistem pendidikan yang memberikan kesempatan kepada anak berkebutuhan khusus untuk belajar bersama- sama dengan anak biasa (normal) di sekolah umum. Dengan demikian, melalui sistem integrasi, anak berkebutuhan khusus bersama- sama dengan anak normal belajar dalam satu atap.

\section{Dekadensi Moral yang Terjadi Akhir- Akhir Ini}

Kita lihat akhir- akhir ini di semua media telah terjadi banyak kerusakan moral yang tentu saja bertentangan dengan nilai- nilai Pancasila. Contohnya seperti tawuran atau perkelahian masal murid- murid SD sampai Perguruan Tinggi dan begitu pula antar warga masyarakat. Selain itu banyaknya baik pejabat pemerintah maupun generasi muda yang memakai narkoba dan minuman keras untuk bermabuk- mabukan sehingga tentunya berakibat timbulnya kerusakan moral. Hal 
inilah menjadi tugas pentingnya PPKN (Pendidikan Pancasila dan Kewarganeraan). Hal ini sesuai pernyataan Zuriah (2007: 3) :

Masalah yang timbul disini adalah hukuman yang berkaitan dengan perilaku siswa yang secara instinktif atau naluriah dijatuhkan oleh pendidik. Naluri ini tidak lain merupakan warisan hati nurani para leluhur dari masa dahulu yang mudah menjatuhkan hukuman terhadap perilaku yang salah. Adat istiadat menempatkan hukum dan paksaan itu di rumah dan di sekolah.

Beberapa sebab banyaknya terjadi dekadensi moral yaitu yang pertama terpenting adalah kurang bertakwa kepada Tuhan khususnya muslim, karena negara Indonesia sebagian besar rakyatnya adalah muslim. Sehingga dengan kurang bertakwa kepada Tuhanlah maka akibatnya banyak terjadi kerusakan moral rakyat baik pejabat maupun non pejabat di seluruh lapisan masyarakat. Hanya sebagian kecil orang- orang yang bertakwa kepada Tuhan. Ajaran- ajaran atau nilainilai agama hanya dijadikan simbol atau penampakan (aksesoris luar tubuh) saja bukan dipraktekkan atau dilakukan. Hal ini sesuai dengan pernyataan Heru dan kawan- kawan
(2002 : 60) yaitu "kita harus mengakui bahwa kedisiplinan rakyat akhir- akhir ini merosot, hampir di semua bidang, hal ini mencerminkan nilai- nilai Ketuhanan Yang Maha Esa tidak kuat lagi, mulai suram. Kesadaran bahwa kita mesti bertanggung jawab kepada sang Pencipta pudar sehingga kejahatan merajalela dan mewabah". Kedua yaitu kurangnya teladan yang baik bagi generasi muda khususnya dalam dunia pendidikan dari PAUD sampai Perguruan Tinggi.

Oleh karena itu ajaran- ajaran agama khususnya Islam yang terkandung dalam Alqur'an adalah untuk semua bidang kehidupan manusia itu sendiri. Sehingga nantinya dengan ketakwaan kepada ajaran- ajaran Islam dapat dilakukan semaksimal mungkin dan diharapkan dapat melahirkan perilaku- perilaku yang baik. Dan tentunya ajaranajaran agama khususnya Islam menyangkut ke salah satu bidang dalam dunia pendidikan yaitu yang dinamakan BK (Bimbingan Konseling). Mengenai tujuan BK di sekolah, hal ini juga didukung oleh Soetjipto (2007 : 65) yaitu bahwa layanan bimbingan konseling sangat penting bagi siswa untuk mengatasi masalah- masalahnya seperti kesulitan belajar, kebiasaankebiasaan yang kurang baik saat proses di dalam kelas maupun di luar kelas, masalah emosinal. 


\section{PENUTUP}

Oleh karena itu betapa pentingnya kaitan antara Pendidikan Pancasila dan Kewarganeraan dalam BK (Bimbingan Konseling) karena dengan sendirinya PPKN akan mengarahkan bidang studi BK di
Indonesia. Tentunya hal inilah yang membedakan bidang studi BK (Bimbingan Konseling) dengan negara lainnya. Jadi bidang studi BK di Indonesia harus berdasarkan Pancasila atau nilai- nilai kepribadian bangsa kita. 
59 Nova Eko Hidayanto: peran ppkn dalam bimbingan konseling ...

\section{DAFTAR PUSTAKA}

Heru Santosa; Yonnie Maristha, S; Rukiyati, Sumaryati. 2002. Sari Pendidikan Pancasila dan UUD 1945 beserta perubahannya. Yogyakarta : PT. Tiara Wacana Yogya

Pujihastuti, Nanik; Triana Rejekiningsih dan Machmud Al Rasyid. 2016. Strategi Guru Pendidikan Pancasila dan Kewarganegaraan pada Pendidikan Inklusi dalam Kurikulum Regular dengan Modifikasi. PKn Progresif : Jurnal Pemikiran dan Penelitian Kewarganegaraan Vol 11 No 2 Desember 2016. Surakarta : Prodi PPKn FKIP Universitas Sebelas Maret.

Soeroso, R. 2007. Pengantar Ilmu Hukum. Jakarta : Sinar Grafika

Soetjipto dan Raflis Kosasi. 2007. Profesi Keguruan. Jakarta : Rineka Cipta.

Zuriah, Nurul. 2007. Pendidikan Moral dan Budi Pekerti dalam Perspektif Perubahan : Menggagas Platform Pendidikan Budi Pekerti secara Kontekstual dan Futuristik. 